\title{
The Predictive Power of Religious Orientation Types on Ambivalent Sexism
}

\author{
Fatih ÖZDEMIR ${ }^{1}$
}

\begin{abstract}
The purpose of the present study was to predict ambivalent sexism (including hostile sexism and benevolent sexism) with religious orientation types as intrinsic religiosity, extrinsic religiosity and quest religiosity. In addition, the effect of demographic variables (including sex, age and education level) on sexist attitudes was tested. $583\left(N_{\text {female }}=318 ; N_{\text {male }}=265\right)$ university students who study in different universities of Ankara/Turkey $\left(M_{a g e}=22.10 ; S D=2.33\right)$ completed Ambivalent Sexism Inventory, and Religious Orientation Scale. Findings indicated significant gender differences on study variables and significant associations between religious orientation types and ambivalent sexism within university students sample in Turkey.

Keywords: hostile sexism, benevolent sexism, intrinsic religiosity, extrinsic religiosity, quest religiosity, Turkish society, Islamic beliefs

Özdemir, F. (2016). The Predictive Power of Religious Orientation Types on Ambivalent Sexism. Nesne, 4(7), 89-107.

\footnotetext{
${ }^{1}$ Research Assistant, Ph.D. Candidate, Middle East Technical University, Psychology Department psyfatihozdemir(at)gmail.com Author Note: The present research is a part of master's thesis which was conducted by author: Psychology Department (Psikoloji Bölümü), Middle East Technical University (Orta Doğu Teknik Üniversitesi), 06800, Ankara, Turkey. Thesis study was financially supported by The Scientific and Technological Research Council of Turkey (TUBITAK).

Author Note: The present research was presented as a poster at the 28th International Congress of Applied Psychology, Paris, France (2014, July).
} 


\title{
Çelişik Duygulu Cinsiyetçilik Üzerinde Dini Yönelim Tiplerinin Yordayici Gücü
}

\begin{abstract}
ÖZ
Mevcut çalışmanın amacı düşmancı cinsiyetçilik ve korumacı cinsiyetçiliği içeren çelişik duygulu cinsiyetçiliği içsel dindarlık, dışsal dindarlık ve sorgulayıcı dindarlık gibi dini yönelim tipleri ile yordamaktır. Ek olarak cinsiyet, yaş ve eğitim seviyesi gibi demografik değişkenlerin cinsiyetçi tutumlar üzerindeki etkisi test edilmiştir. Ankara (Türkiye)'nın farklı üniversitelerinde eğitim gören $583 \quad\left(N_{\text {kadın }}=318 ; N_{\text {erkek }}=265, \quad\right.$ Ort $\left._{\text {yaș }}=22.10 ; S S=2.33\right)$ üniversite öğrencisi Çelişik Duygulu Cinsiyetçilik Envanteri ve Dini Yönelim Ölçeği'ni çalışma kapsamında doldurmuştur. Bulgular araştırma değişkenleri üzerinde anlamlı cinsiyet farklılıklarını ve Türkiye'de üniversite öğrencileri örneklemi içerisinde dini yönelim tipleri ve çelişik duygulu cinsiyetçilik arasındaki anlamlı ilişkileri göstermektedir.
\end{abstract}

Anahtar Sözcükler: düşmancı cinsiyetçilik, korumacı cinsiyetçilik, içsel dindarlık, dışsal dindarlık, sorgulayıcı dindarlık, Türk toplumu, İslami inançlar 
In spite of some pro-gender equality movements, intellectual developments and modernization desire, Turkish society still protects its male-dominant and gendered characteristics (e.g., Glick, Sakall1-Uğurlu, Akbaş, Metin-Orta, \& Ceylan, 2015; İlkkaracan, 1998; Sakallı-Uğurlu, Yalçın, \& Glick, 2007; Sünbüloğlu, 2013). On the global gender gap index (2014) of World Economic Forum, Turkey ranked 125 th out of 142 countries as a result of patriarchal values, male domination and female subordination in society. The purpose of the present study is to understand the underlying mechanism of current gender-based social hierarchy, investigate sexist attitudes toward women which subjectively rationalize gender-based inequality, and test its possible associations with religious orientation types within Muslim-Turkish society in a survey-based methodology.

\section{Ambivalent Sexism in Turkish Society}

Turkish society is an interesting community which squeezes between different ideologies such as East-West, secularism-religiosity, modernismtraditionalism (Glick et al., 2015); but basically, Turkish people live in a gender-based hierarchical structure with the effect of traditional, conservative and religious ideologies (Cagaptay, 2006; Kağıtçıbaşı, 1982; Kağıtçıbaşı \& Sunar, 1992; Karakitapoğlu-Aygün \& İmamoğlu, 2002; Schwartz, 1994). For example, even if Turkish government aims to protect gender equality with legal codes and laws in official ways (Heper, 1985), masculinity and femininity concepts, male-dominant socio-cultural and religious ideologies mostly are used as matters of extenuation for the cases of violence toward woman and woman killing by courts.

Honor cultures, such as Turkey, highlight patriarchal values (rule by fathers) which men dominate and control women in social and ideological structure (Walby, 1990), and male is perceived as an authority figure in different contexts of life (Kağıtçıbaşı, 1982; Kağıtçıbaşı \& Sunar, 1992). This gender-based hierarchy and priority of men shape the meaning of masculinity and femininity concepts. For example, active characteristics such as independent, risk-taking, self-sufficient, dominant, strong personality and active leadership abilities are related with masculinity; whereas, passive characteristics such as dependent, warm, tender, gentle, affectionate and sympathetic are associated with femininity in Turkey (Özkan \& Lajunen, 2005). When Turkish men compared Turkish women with men, they defined women as more childish, dependent, emotional, irrational, submissive, ignorant, less intelligent, and weaker than men (Sunar, 1982). This indicates that masculinity (e.g., rational, active, logical, autonomous etc.) and femininity (e.g., emotional, passive, illogical, connected etc.) concepts are evaluated as opposite poles (Carreiras, 2004). This perspective indicates its effects on different institutions of society. For example, Turkish parents mostly indicate more tolerance to sons' aggressive and independent 
behaviors; but they mostly promote obedient and dependent actions of their daughters (Başaran, 1974).

The privileged and dominant position of man is legitimized with sexist attitudes toward woman. Sexism is conceptualized as the expression of hostile attitude toward woman; but this perspective ignores subjectively positive and gender-based stereotypical attitudes. Glick and Fiske (1996; 2001) differentiate hostile sexism, overt hostile and negative attitudes which evaluate women as a threat for traditional roles and male domination, from benevolent sexism, subjectively protective and positive but dominative attitudes which define woman as weak and fragile, and needs the protection of man. Both hostile sexism and benevolent sexism idealize women in traditional gender hierarchy, and strengthen gender-based inequality (Glick \& Fiske, 2001).

Sexism can be evaluated as the product of socio-cultural and political system within the perspective of system justification theory (Jost \& Kay, 2005). Based on theory, "people want to hold favorable attitudes about themselves, and about their own groups; but they also want to hold favorable attitudes about social, and political systems that affect them" (Jost, Banaji, \& Nosek, 2004, p. 887). Some items of benevolent sexism sub-scale (e.g., women, compared to men, tend to have a superior moral sensibility; many women have a quality of purity that few men possess) provide subjectively positive self and group-based image for women, and justify current gender-based system within subjectively complementary context for both gender groups (e.g., no matter how accomplished he is, a man is not truly complete as a person unless he has the love of a women). Besides all these, benevolent sexism strengthens the protective paternalism, male domination and inferior position of woman (e.g., women should be cherished and protected by men; a good woman should be set on a pedestal by her man; men should be willing to sacrifice their own well-being in order to provide financially for the women in their lives), and woman is represented as pure, weak, incompetent and needs to male protection. Also, men's superior position is justified via these items; men can gain greater power or resource to improve the conditions of woman in their life. On the other hand, the items of hostile sexism subscale evaluate women as a threat or challenge for male domination (e.g., women seek to gain power by getting control over men; once a woman gets a man to commit to her, she usually tries to put him on a tight leash), indicate overt hostile attitudes and demean woman. That is why hostile sexism satisfies self, group-based and system justification motives for males. According to system justification theory, the internalization of current system mostly may be stronger not only among superior group members but also among disadvantageous group members (Altınay, 2004; Haines \& Jost, 2000; Sünbüloğlu, 2013). When we consider sexism literature, and the sexist attitudes of men and women are compared, in highly sexist societies, men 
express hostile sexist attitudes more freely than women; whereas mostly there is not a significant gender difference on the expression of benevolent sexist attitudes and both gender groups get high sexism scores (Sibley, Overall, \& Duckitt, 2007) or women indicate greater benevolent sexism than men (Glick et al., 2000; 2004).

Turkish people tend to support social hierarchy (Hofstede, 2001; 2011), and both hostile sexism and benevolent sexism are positively associated with genderbased social hierarchy. Especially, the endorsement of benevolent sexism by women provides subjective justifications for male dominations, and strengthens current gender-based system. This situation also increases the acceptance of hostile sexism by women; for example, there is a positive association between hostile sexism and benevolent sexism in most studies (Glick et al., 2000, 2004). Also, within American; Canadian and New Zealander samples, initial benevolent sexism scores of woman undergraduate students predicted their later hostile sexism scores, and these women evaluated current gendered system as fair (Jost \& Kay, 2005; Sibley et al., 2007).

\section{Religious Orientation Types and Ambivalent Sexism}

Divine religions mostly include discourses about equality of human beings. However, when religious discourses are evaluated detachedly, this can be realized that some groups of people are not equal to others. For example, although some of Qur'an verses (e.g., al-Nisa, 4:1; al-Ahzab, 33:35; al-An'am, 6:164, al-Baqarah, 2:228) emphasize equality of human beings and egalitarian gender system such as,

\footnotetext{
"Both men and women, by virtue of their being in the world, are God's creatures; Men and women as persons (selves), partners, members of society, and servants of God are obliged to respect each other; Men and women are jointly responsible for preventing evil and promoting good; Men and women as persons, partners, members of society, and God's creatures and servants are, therefore, equally expected to maintain each other's rights in order to be recompensed in the hereafter" (Anwar, 2006, p. 21),
}

Islamic beliefs mostly include hostile and benevolent justifications for male dominance and inferior position of women (e.g., Anwar, 2006) such as

"Men shall take full care of women with the bounties, which God has bestowed more abundantly on the former than on the latter, and with what they may spend out of their possessions. And the righteous women are the truly devout ones, who guard the intimacy (al-Nisa, $4: 34) ; \ldots$ and if there are brothers and sisters, the male shall have the equal of two females' share (al-Nisa, 4:176); And call upon two of your men to act 
as witnesses; and if two men are not available, then a man and two women from among [acceptable witnesses to you], so that if one of them should make a mistake, the other would remind her (al-Baqarah, 2:282)" (Anwar, 2006, p. 18).

In Islamic beliefs and Qur'an verses, women are represented as the object of man power, and mostly men of family (e.g., husband, father, brother etc.) shape the life of woman. Qur'an also identifies the characteristics of idealized woman as salient, subservient and obedient.

It is also a fact that the fusion of Islamic beliefs with local cultures may create different public gender-based expressions. The Pew Research Center and Turkish government records (2011) indicate that $98.6 \%$ of total Turkish population was Muslim (about 75-million people). However, all Muslim individuals may not indicate same religious orientation, and they may interpret religious doctrines in different perspectives. As stated previously, the current study aims to test the predictive power of religious orientation types (including intrinsic, extrinsic and quest religious orientations) on hostile and benevolent sexist attitudes.

The religiousness of individuals and their religious orientations can be explained with the person's priority about intrinsic or extrinsic benefits of religion intrinsic or extrinsic religious orientation. Allport and Ross (1967) define the difference of religious people as "the extrinsically motivated person uses his religion, whereas the intrinsically motivated lives his religion" (p. 434). Intrinsically oriented person has a mature religious approach, and considers religion as the master motive in life, and ultimate benefit in itself; other needs and goals are less important than religious satisfaction, and these needs and goals should be brought in harmony with religious concepts or beliefs. However, extrinsically oriented individuals consider their religion with a self-centered, immature, pragmatic and instrumental perspective (Allport \& Ross, 1967); they use their religion to reach external benefits and satisfy social needs such as security, social contact, social status or acceptance from society.

Besides intrinsic and extrinsic religious orientations, quest religiosity is considered as other form of religiousness (Altemeyer \& Hunsberger, 1992; 2004; Batson, 1976; Batson \& Stocks, 2005). These individuals perceive religious truths as conditional (Batson, Schoenrade, \& Ventis, 1993), and criticize the perspective which accepts religious doctrines as absolute and unquestionable. They tend to reevaluate the nature, questions and assumptions of religion - meaning of life, existence of God and afterlife - without simplifying or reducing their complexity. In other words, they do not accept the rules and assumptions of their religion doubtlessly. Quest religious people define doubt as a positive and necessary characteristic for improvement, and 
emphasize the tentativeness of religious answers; but also they do not refuse the possibility of absolute truth completely. These people are defined as open-minded, flexible and critical individuals (Batson, 1976).

Religious orientation type is found to be related with different psychological constructs. For example, extrinsically religious oriented people desire to satisfy their social needs, and they show more conformity to social norms and expectations than intrinsically oriented people (Allport \& Ross, 1967). Therefore, it is possible to argue that extrinsically oriented people may support the current gender-based social system of Turkish society. Besides that, when male domination and female subordinationbased Qur'an verses and hostile and benevolent sexist Islamic beliefs are considered, intrinsically oriented Muslim people also may support sexist attitudes.

When quest religious orientation is analyzed, according to findings of metaanalysis, quest religiosity is positively related with openness to change and high tolerance to dissent or out-groups, and these people indicate less identification with norms, values and traditions of current social system without questioning (Saroglou, 2002). Also, the meta-analysis of McClearly, Quillivan, Foster, and Williams (2011) shows that quest religiosity is negatively correlated with authoritarianism, ethnocentrism and prejudice. When the positive prediction of openness to change and tolerance to out-group, and the negative prediction of authoritarianism and prejudice on sexual discrimination are considered, quest religiosity may be negatively associated with hostile and benevolent sexist attitudes toward women.

\section{The Aim of the Current Study}

As stated previously, the purpose of the present paper is to predict hostile and benevolent sexist attitudes toward woman with religious orientation types in the sense of man and woman within college students sample. Also, the association between demographic attributes of participants (including sex, age and education level) and their sexist attitudes will be investigated. Depending on the findings of literature;

Hypothesis 1 - Men would show hostile sexist attitude more freely than women; but there would not be gender difference on benevolent sexism.

Hypothesis 2 - Demographic variables such as age and education level would predict hostile and benevolent sexist attitudes. Specifically people, who are younger and have lower education level, would get higher scores on hostile and benevolent sexism.

Hypothesis 3 - Intrinsic and extrinsic religious orientations would support both hostile sexism and benevolent sexism, but quest religious orientation would decrease hostile and benevolent sexist attitudes after controlling demographic variables such as sex, age and education level. 


\section{Method}

\section{Participants}

Five hundred eighty three university students (including both undergraduate and graduate levels) who study in different universities of Turkey's capital city Ankara such as Gazi University $(N=198)$, Hacettepe University $(N=138)$, Middle East Technical University $(N=120)$ and Ufuk University $(N=127)$ participated in the present study. There were 318 female $(54.5 \%)$ and 265 male $(45.5 \%)$ participants. The age of participants changed from 18 to 30 , with a mean age of $22.10(S D=2.33)$.

\section{Instruments}

Ambivalent Sexism Inventory: The scale was developed by Glick and Fiske (1996) to measure hostile sexism (11-item; including dominative paternalism, competitive gender differentiation and hostile heterosexuality) and benevolent sexism (11-item; including protective paternalism, complementary gender differentiation and intimate heterosexuality). Sakallı-Uğurlu (2002) adopted it into Turkish. Internal consistency of hostile sexism was .87 and of benevolent sexism was .78 in Turkish sample (Sakall1-Uğurlu, 2002). Few examples of hostile sexism are "Women seek to gain power by getting control over men", "Many women are actually seeking special favors, such as hiring policies that favor them over men, under the guise of asking for equality", and "Most women interpret innocent remarks or acts as being sexist". Few examples of benevolent sexism are "Women should be cherished and protected by men", "Many women have a quality of purity that few men possess", and "Every man ought to have a woman he adores".

In the present study, participants indicated what extent they have supported statements using 7-point Likert scale which ranged from "strongly disagree" to "strongly agree." Higher scores showed stronger endorsement of hostile sexism and benevolent sexism. The internal consistency was .89 for hostile sexism; and .86 for benevolent sexism.

Religious Orientation Scale: The scale was developed by Sakall1-Uğurlu and Shaver (2013) to assess religious orientation forms such as intrinsic religious orientation (6item), extrinsic religious orientation (4-item), quest religious orientation (5-item) and fundamentalist religious orientation (4-item). Internal consistencies of intrinsic, extrinsic, quest and fundamentalist religious orientations were $.88, .73, .74, .73$ in American Christian sample and .84, .70, .76, .73 in Turkish Muslim sample, respectively. Few examples of intrinsic religious orientation are "I believe in God because of what I feel inside", "For me, worship is not a way of asking favors from 
God, but rather a way of feeling God's peaceful presence"; for extrinsic religious orientation are "My intention in praying is to ensure a happy and peaceful life", "The most important reason for practicing my religion is to gain God's help and protection"; for quest religious orientation are "I cannot accept my religion the way it is presented without questioning", "As I grow and change, my religion also grows and changes with me"; for fundamentalist religious orientation are "Religious rules are unchangeable and an integral part of the religion; you either accept or reject all of them as they are", "I think that questioning and reinterpreting the rules of religion is the same as opposing the religion".

In the present study, because of high negative correlation between quest and fundamentalist religious orientations, they were accepted as conceptually overlapped. In order to prevent suppression effect, the items of fundamentalist religiosity were coded as reverse, and combined into single factor with quest religiosity items. Participants indicated their religious orientations using 7-point Likert scale that ranged from "strongly disagree" to "strongly agree". Higher scores of sub-scales indicated stronger identification with intrinsic, extrinsic and quest religious orientations. The internal consistency was .92 for intrinsic religiosity; .80 for extrinsic religiosity; and .83 for quest religiosity.

\section{Procedure}

The present research was performed in different universities of Ankara with the permission of ethical review board of Middle East Technical University. Study was conducted in accordance to APA ethical standards (http://www.apa.org/ethics/code/principles.pdf). The informed consent form was provided to participants, and students filled out questionnaire package consisting of measures for ambivalent sexism, religious orientation and demographic information on the basis of their voluntary participation in classroom environment. In order to strengthen the generalizability of findings, both different universities and common courses which are available for all departments were preferred to collect data. Each data collection session lasted about 20 minutes, and at the end of sessions, researchers answered the questions of participants. The data of the study was collected within three weeks. 


\section{Results}

\section{Preliminary Analyses}

Before testing the main hypotheses of research, preliminary analyses as gender differences and correlations among study variables were tested in order to test proposed first hypothesis (that men would show hostile sexist attitude more freely than women; but there would not be gender difference on benevolent sexism) and understand main structure of collected data.

\section{Gender Differences}

A one-way MANOVA was performed to test gender differences on hostile sexism, benevolent sexism, intrinsic religious orientation, extrinsic religious orientation, quest religious orientation and demographic variables (including age and education level). The analysis demonstrated a significant gender effect; Wilks' $\lambda=$ $.78, F(7,575)=23.51, p<.001$. Results (see means and standard deviations in Table 1) showed significant gender differences on hostile sexism, $F(1,581)=58.88, p<$ .001 ; intrinsic religious orientation, $F(1,581)=14.69, p<.001$; age, $F(1,581)=$ $25.50, p<.001$ and education level, $F(1,581)=5.21, p<.05$. Specifically, men $(M$ $=4.80 ; S D=1.22)$ indicated greater hostile sexism than women $(M=4.04 ; S D=1.15)$; but there was not a significant gender difference on benevolent sexism, and both men and women expressed benevolent sexist attitudes. Therefore, the first hypothesis was supported (see other gender differences in Table 1).

\section{Correlation among Dependent and Independent Variables}

Table 1 reports zero-order correlations among study variables, computed separately for male and female participants. Results indicated that hostile sexism was positively correlated with benevolent sexism, intrinsic religiosity and extrinsic religiosity; and negatively associated with quest religious orientation and education level for both men and women. In addition, hostile sexism was negatively correlated with age for men. Secondly, benevolent sexism was positively related with intrinsic religiosity and extrinsic religiosity; and negatively associated with quest religious orientation, age and education level for both men and women (see all correlations among the variables of the present study in Table 1). 
Table 1. Means, Standard Deviations and Inter-Correlations of Study Variables for Women $(N=318)$ and $\operatorname{Men}(N=265)$

\begin{tabular}{|c|c|c|c|c|c|c|c|c|c|}
\hline Variable & $\begin{array}{l}M(S D) \\
\text { Women }\end{array}$ & $\begin{array}{c}M(S D) \\
\text { Men }\end{array}$ & 1 & 2 & 3 & 4 & 5 & 6 & 7 \\
\hline 1. HS & $\begin{array}{c}4.04 \\
(1.15)\end{array}$ & $\begin{array}{c}4.80 \\
(1.22)\end{array}$ & --- & $.47 * *$ & $.39 * *$ & $.43^{* *}$ & $-.37 * *$ & $-.24 * *$ & $-.22 * *$ \\
\hline 2. BS & $\begin{array}{c}4.54 \\
(1.20)\end{array}$ & $\begin{array}{c}4.38 \\
(1.23)\end{array}$ & $.48 * *$ & ---- & $.46^{* *}$ & $.47 * *$ & $-.30 * *$ & $-.13^{*}$ & $-.16^{* * *}$ \\
\hline 3. IRO & $\begin{array}{c}5.80 \\
(1.36)\end{array}$ & $\begin{array}{c}5.32 \\
(1.65)\end{array}$ & $.37 * *$ & $.50 * *$ & ---- & $.60 * *$ & $-.44 * *$ & -.03 & -.07 \\
\hline 4. ERO & $\begin{array}{c}4.07 \\
(1.53)\end{array}$ & $\begin{array}{c}3.83 \\
(1.71)\end{array}$ & $.41 * *$ & $.52 * *$ & $.59 * *$ & ---- & $-.49 * *$ & -.09 & $-.15^{*}$ \\
\hline 5. QRO & $\begin{array}{c}4.25 \\
(1.32)\end{array}$ & $\begin{array}{c}4.24 \\
(1.31)\end{array}$ & $-.26 * *$ & $-.40 * *$ & $-.40 * *$ & $-.52 * *$ & ---- & .09 & $.24 * *$ \\
\hline 6. AGE & $\begin{array}{l}21.66 \\
(2.01)\end{array}$ & $\begin{array}{l}22.62 \\
(2.57)\end{array}$ & -.09 & $-.20 * *$ & -.07 & -.11 & .11 & ---- & $.44^{* *}$ \\
\hline 7. EDU & $\begin{array}{l}1.07 \\
(.25)\end{array}$ & $\begin{array}{l}1.12 \\
(.33)\end{array}$ & $-.19 * *$ & $-.26 * *$ & $-.17 * *$ & $-.13^{*}$ & $.17 * *$ & $.54 * *$ & ---- \\
\hline
\end{tabular}

Note. Inter-correlations for female participants are shown below the diagonal; for male participants, above the diagonal. $\mathrm{HS}=$ hostile sexism; $\mathrm{BS}=$ benevolent sexism; IRO = intrinsic religious orientation; $\mathrm{ERO}=$ extrinsic religious orientation; $\mathrm{QRO}$ = quest religious orientation; AGE = age; EDU = education level. Scales ranged from 1 (strongly disagree) to 7 (strongly agree). EDU grouped in two categories as $1=$ undergraduate; $2=$ graduate. Higher means on HS and BS indicate stronger sexist attitudes toward women. Higher scores on IRO, ERO and QRO indicate stronger intrinsic, extrinsic and quest religious orientations. Higher scores on AGE and EDU show older ages and higher education levels. $* * p<.01 ; * p<.05$.

\section{Main Hypothesis Testing: The Predictors of Hostile Sexism and Benevolent Sexism}

In order to test proposed second and third hypotheses (that age, education level and religious orientation types would predict hostile sexism and benevolent sexism), hierarchical regression analyses were conducted. In the first step, the predictive powers of sex, age and education level were tested, whereas in the second step intrinsic, extrinsic and quest religious orientations entered into the equation.

As can be seen in Table 2, results indicated that sex $(\beta=.34, t=8.50, p<$ $.001)$, age $(\beta=-.09, t=-1.94, p<.06$, marginally) and education level $(\beta=-.15, t=-$ $3.45, p<.001)$ significantly predicted hostile sexism $\left(R^{2}=.14, F(3,579)=30.17, p\right.$ $<.001)$. In the second step, intrinsic religiosity $(\beta=.18, t=3.92, p<.001)$, extrinsic religiosity $(\beta=.24, t=5.16, p<.001)$ and quest religiosity $(\beta=-.08, t=-1.89, p<$ .06 , marginally) were significant predictors of hostile sexism $\left(R^{2}=.30, F(6,576)=\right.$ $41.70, p<.001)$. When benevolent sexism was tested, it was significantly explained by education level $(\beta=-.16, t=-3.54, p<.001),\left(R^{2}=.05, F(3,579)=10.51, p<\right.$ $.001)$. In the second step, intrinsic religiosity $(\beta=.27, t=6.03, p<.001)$, extrinsic religiosity $(\beta=.28, t=6.13, p<.001)$ and quest religiosity $(\beta=-.08, t=-1.97, p<$ $.05)$ significantly predicted benevolent sexism $\left(R^{2}=.32, F(6,576)=46.09, p<.001\right)$. 
In sum, second and third hypotheses of the study were supported (excluding the association between age and benevolent sexism).

Table 2. Regression Analyses to Predict HS and BS $(N=583)$

\begin{tabular}{|c|c|c|c|c|c|c|}
\hline \multirow[t]{2}{*}{ Variable } & \multicolumn{3}{|c|}{ Hostile Sexism } & \multicolumn{3}{|c|}{ Benevolent Sexism } \\
\hline & $B$ & $S E B$ & $\beta$ & $B$ & $S E B$ & $\beta$ \\
\hline SEX & .83 & .10 & $.34 * *$ & -.08 & .10 & -.03 \\
\hline AGE & -.05 & .02 & $-.09 *$ & -.05 & .03 & -.09 \\
\hline EDU & -.65 & .19 & $-.15 * *$ & -.68 & .19 & $-.16^{* *}$ \\
\hline$F$ & 30.17 & & & 10.51 & & \\
\hline$R^{2}$ & $.14 * *$ & & & $.05 * *$ & & \\
\hline IRO & .14 & .04 & $.18 * *$ & .21 & .04 & $.27 * *$ \\
\hline ERO & .18 & .04 & $.24 * *$ & .21 & .03 & $.28 * *$ \\
\hline QRO & -.07 & .04 & $-.08 *$ & -.07 & .04 & $-.08^{*}$ \\
\hline$F$ & 41.70 & & & 46.09 & & \\
\hline$R^{2}$ & $.30^{* *}$ & & & $.32 * *$ & & \\
\hline
\end{tabular}

Note. $\mathrm{HS}=$ hostile sexism; $\mathrm{BS}=$ benevolent sexism; IRO = intrinsic religious orientation; $\mathrm{ERO}=$ extrinsic religious orientation; $\mathrm{QRO}=$ quest religious orientation; $\mathrm{SEX}=\mathrm{sex} ; \mathrm{AGE}=$ age; EDU = education level. Scales ranged from 1 (strongly disagree) to 7 (strongly agree). SEX grouped in two categories as $1=$ female; $2=$ male. EDU grouped in two categories as 1 = undergraduate; 2 graduate. Higher means on HS and BS indicate stronger sexist attitudes toward women. Higher scores on IRO, ERO, and QRO indicate stronger intrinsic, extrinsic and quest religious orientations. Higher scores on AGE and EDU show older ages and higher education levels. $* * p<.01 ; * p<.06$ (marginally significant).

\section{Discussion}

The purpose of the present paper was to predict hostile and benevolent sexist attitudes toward woman with religious orientation types within college students sample. In addition, the association between demographic attributes of participants (including sex, age and education level) and sexist attitudes was investigated in an empirical methodology.

\section{Brief Discussion on Gender Differences toward Study Variables}

In the present research, men expressed greater hostile sexism than women; but significant gender difference on benevolent sexism could not be found. This finding is consistent with existing literature in Turkey (e.g., Taşdemir \& Sakall1Uğurlu, 2010). Also Glick, Sakall-Uğurlu, Ferreira and Souza (2002) proposed that even if women do not accept hostile sexism, they tend to indicate benevolent sexist attitudes in highly sexist societies; because benevolent sexism subjectively provides protection and affection for women. 
When the religiosity of sample was considered, high religiosity scores of both gender groups indicated that religiousness is one of the main characteristics of Turkish society (Cagaptay, 2006). Females indicated stronger intrinsic religiosity than males. Significant gender difference on intrinsic religiosity should not be surprising; because women are defined as more religious than men in the sociology of religion field (Vaus \& McAllister, 1987). In addition, there was not significant gender difference on extrinsic and quest religious orientation scores. Demographic variables such as age and education level may influence religious orientation level of individuals. The present study was conducted within university students sample, and homogeneity of sample may prevent gender difference on some religious orientation types. For example, Flere (2007) conducted a study among university students, and could not find gender difference on extrinsic and quest religiosity.

\section{Predictive Powers of Independent Variables on Hostile Sexism and Benevolent Sexism}

Intrinsic and extrinsic religious orientations positively predicted both hostile sexism and benevolent sexism after controlling demographic variables such as sex, age and education level. When patriarchal value-based Islamic beliefs and Qur'an verses are considered, the sexist attitudes of intrinsically oriented people can be evaluated as an expected finding. Secondly, as stated before, extrinsic religious individuals have a self-centered and pragmatic perspective; they are religious to gain external benefits and satisfy their social needs such as security, social contact, social status and taking the approval of society (Allport \& Ross, 1967; McClearly et al., 2011; Saroglou, 2002). Because of the same motivation, they indicate greater conformity to current social norms, and support traditional systems. The gender-based socio-hierarchical structure and male-dominant characteristics are highly related with the perceived socio-cultural, economic and political reality of Turkish society (e.g., Glick et al., 2015; Hofstede, 2001; İlkkaracan, 1998; Sakall1-Uğurlu et al., 2007; Sünbüloğlu, 2013).

Besides intrinsic and extrinsic religious orientations, quest religious orientation negatively predicted hostile sexism and benevolent sexism. Individuals who indicate quest religious orientation are defined as open-minded, flexible and critical (Batson, 1976), and tend to criticize and reevaluate the doctrines and assumptions of religion (Batson et al., 1993). This critical perspective may indicate its effect on different contexts. That is why we proposed that people who have quest religious orientation would not accept current gender-based traditional system of Turkish society doubtlessly, and findings of the current study supported this assumption. 
Lastly, when participants' demographic information is considered, hostile sexism was more common among males than females (Sibley et al., 2007); but new experiences with time (age) may decrease hostile sexist attitudes. Also, there was a negative association between education level and sexism; because education may strengthen the self-worth perception of women, and may increase the awareness for negative consequences of hostile and benevolent sexist attitudes.

In sum, based on the statistical findings of the present study, it can be concluded that demographical variables (including sex, age and education level) were better predictors for hostile sexism whereas religious orientation types (including intrinsic, extrinsic and quest religiosity) explained greater variance on benevolent sexism.

\section{Limitations and Future Directions}

Limitations of the study should be taken into consideration. Even if the study was conducted in different universities of Ankara to access different participant profiles and mitigate the effect of sample on generalizability, findings can be used to explain sexist attitudes of college students. Future researches should cover data from outside of university and increase demographic information range (including age, education level etc.) to provide better representative data and reach valid generalizations for Turkish society. Secondly, sexism and religiosity are delicate issues in Turkish society, and social desirability may influence the answers of participants; that is why the short form of social desirability scale (Crowne \& Marlowe, 1960) should be added to control social desirability tendency in future studies.

\section{Practice Implications}

The present study may provide important contributions with theoretical and practical aspects. Firstly, the gender-based socio-hierarchical structure of Turkish society influences social behaviors of individuals. Patriarchal values and maledominant social structures shape formal and informal institutions of society from family (Kağıtçıbaşı, 1982; Kağıtçıbaşı \& Sunar, 1992) to military (Kuloğlu, 2005). In addition, when gender-based problems of Turkey (including gender inequality, violence toward woman and honor killings etc.) are considered, social psychologists should conduct more studies on sexism issue. Study findings may support the literature on sexism and religiosity, and provide a chance to test main theoretical assumptions of sexism studies in Muslim country. Secondly, the present study may provide important findings about underlying mechanism of Turkish gender-based system and associations between sexist attitudes and religiosity. The sexism literature 
mostly focuses on religiousness level rather than religious orientation types. However, all religious people who live based on same religion discourses may not evaluate religious doctrines in same perspective. Based on individual interpretations and orientations, the differences within same religion may be higher than the differences between religions. In practical manner, study findings may be useful to establish an egalitarian social system rather than gender-based hierarchy in a Muslim society.

\section{Conclusions}

The present study, in general, demonstrated that religious orientation types and particular demographic variables such as sex, age and education level are significantly associated with hostile and benevolent sexist attitudes of individuals toward women. Sexism is a multi-dimensional issue, and women are exposed to gender-based discrimination in many parts of their lives. In addition, gender-based discrimination is not the problem of Turkish society only, and sexism can be seen in many cultures. That is why literature needs more research to clarify underlying dimensions of sexism. Findings of this type studies can be used by politicians, lawmakers and other formal authorities to decrease hostile sexism and benevolent sexism in society, and prevent gender-based inequality. In addition, it may be beneficial to conduct cross-cultural researches. Similarities and differences among cultures may provide an important insight toward sexism issue.

\section{Kaynaklar}

Allport, G. W., \& Ross, J. M. (1967). Personal religious orientation and prejudice. Journal of Personality and Social Psychology, 5, 432-443. http://dx.doi.org/10.1037/h0021212

Altemeyer, B., \& Hunsberger, B. (1992). Authoritarianism, religious fundamentalism, quest, and prejudice. The International Journal for the Psychology of Religion, 2(2), 113- 133. http://dx.doi.org/10.1207/s15327582ijpr0202_5

Altemeyer, B., \& Hunsberger, B. (2004). A revised religious fundamentalism scale: The short and sweet of it. International Journal for the Psychology of Religion, 11, 47-54. http://dx.doi.org/10.1207/s15327582ijpr1401_4

Altınay, A. G. (2004). The myth of the military-nation: Militarism, gender and education in Turkey. New York: Palgrave Macmillan Press. 
Anwar, E. (2006). Gender and self in Islam. Oxon: Routledge.

Başaran, F. (1974). Psiko-sosyal gelişim (psycho-social development). Ankara: Ankara University Press.

Batson, C. D. (1976). Religion as prosocial: Agent or double agent? Journal for the Scientific Study of Religion, 15, 29-45. http://dx.doi.org/10.2307/1384312

Batson, C. D., Schoenrade, P., \& Ventis, W. L. (1993). Religion and the individual: A social-psychological perspective. New York: Oxford University Press.

Batson, C. D., \& Stocks, E. L. (2005). Religion and prejudice. In J. F. Dovidio, P. S. Glick, and L. Rudman (Eds.). On the nature of prejudice: Fifty years after Allport (p. 413-427). Oxford: Blackwell.

Cagaptay, S. (2006). Islam, secularism and nationalism in modern Turkey: Who is a Turk? London: Routledge.

Carreiras, H. (2004). Gender and the military: A comparative study on the participation of the women in the armed forces of Western democracies. Doctoral Dissertation, European Research Institute, Florence.

Crowne, D. P., \& Marlowe, D. (1960). A new scale of social desirability independent of psychopathology. Journal of Consulting Psychology, 24(4), 349-354. http://dx.doi.org/10.1037/h0047358

Flere, S. (2007). Gender and religious orientation. Social Compass, 54(2), 239-253. http://dx.doi.org/10.1177/0037768607077035

Glick, P., \& Fiske, S. T. (1996). The ambivalent sexism inventory: Differentiating Hostile and Benevolent Sexism. Journal of Personality and Social Psychology, 70(3), 491-512. http://dx.doi.org/10.1037/0022-3514.70.3.491

Glick, P., \& Fiske, S. T. (2001). An ambivalent alliance: Hostile and benevolent sexism as complementary justifications for gender inequality. American Psychologist, 56(2), 109-118. http://dx.doi.org/10.1037/0003066X.56.2.109

Glick, P., Fiske, S. T., Mladinic, A., Saiz, J. L., Abrahms, D., Masser, B., ... Lopez, W. L. (2000). Beyond prejudice as simple antipathy: Hostile and 
benevolent sexism across cultures. Journal of Personality and Social Psychology, 79, 763-775. http://dx.doi.org/10.1037/0022-3514.79.5.763

Glick, P., Lameiras, M., Fiske, S. T., Eckes, T., Masser, B., Volpato, C., ... Wells, R. (2004). Bad but bold: Ambivalent attitudes toward men predict gender inequality in 16 nations. Journal of Personality and Social Psychology, 86, 713-728. http://dx.doi.org/10.1037/0022-3514.86.5.713

Glick, P., Sakallı-Uğurlu, N., Akbaş, G., Metin-Orta, İ., \& Ceylan, S. (2015). Why do women endorse honor beliefs? Ambivalent sexism and religiosity as predictors. Sex Roles, 1-12. http://dx.doi.org/10.1007/s11199-015-0550-5

Glick, P., Sakallı-Uğurlu, N., Ferreira, M. C., \& Souza, M. A. (2002). Ambivalent sexism and attitudes toward wife abuse in Turkey and Brazil. Psychology of Women Quarterly, 26, 292-297. http://dx.doi.org/10.1111/1471-6402.t01-100068

Haines, E. L., \& Jost, J. T. (2000). Placating the powerless: Effects of legitimate and illegitimate explanation on effect, memory, and stereotyping. Social Justice Research, 13(3), 219-236.

Heper, M. (1985). The state tradition in Turkey. Wolkington: Eothen.

Hofstede, G. (2001). Culture's consequences: Comparing values, behaviors, institutions, and organizations across nations. London: Sage.

Hofstede, G. (2011). Dimensionalizing cultures: The Hofstede model in context. Online Readings in Psychology and Culture, 2(1), 1-26.

http://dx.doi.org/10.9707/2307-0919.1014

İlkkaracan, P. (1998). Doğu Anadolu'da kadın ve aile. İstanbul: Tarih Vakfı Yayınlar1.

Jost, J. T., Banaji, M. R., \& Nosek, B. A. (2004). A decade of system justification theory: Accumulated evidence of conscious and unconscious bolstering of the status quo. Political Psychology, 25(6), 881-919. http://dx.doi.org/10.1111/j.1467-9221.2004.00402.x

Jost, J. T., \& Kay, A. C. (2005). Exposure to benevolent sexism and complementary gender stereotypes: Consequences for specific and diffuse forms of system justification. Journal of Personality and Social Psychology, 88(3), 498-509. http://dx.doi.org/10.1037/0022-3514.88.3.498 
Kağıtçıbaşı, Ç. (1982). Sex roles, value of children and fertility. In Ç. Kağıtçıbaşı (Ed.), Sex roles, family and community in Turkey (pp. 151-180).

Bloomington, IN: Indiana University Press.

Kağıtçıbaşı, Ç., \& Sunar, D. (1992). Family and socialization in Turkey. In. J. L. Roopnarine and D. B. Carter (Eds.), Annual advances in applied developmental psychology: Vol. 5. Parent-child socialization in diverse cultures (pp. 75-88). Norwood, NJ: Ablex.

Karakitapoğlu-Aygün, Z., \& İmamoğlu, E. O. (2002). Value domains of Turkish adults and university students. The Journal of Social Psychology, 142, 333351.

Kuloğlu, C. (2005). The military in Turkey from a gender perspective. Master's Thesis, Middle East Technical University, Ankara.

McClearly, D. F., Quillivan, C. C., Foster, L. N., \& Williams, R. L. (2011). Metaanalysis of correlational relationships between perspectives of truth in religion and major psychological constructs. Psychology of Religion and Spirituality, 3(3), 163-180.

Özkan, T., \& Lajunen T. (2005). Masculinity, femininity, and the Bem sex role inventory in Turkey. Sex Roles, 52(1), 103-110.

Pew Research Center. (2011). The Future of the Global Muslim Population. Washington: Religion \& Public Life. Retrieved from http://www.pewforum.org/2011/01/27/the-future-of-the-global-muslimpopulation/.

Sakall1-Uğurlu, N. (2002). Çelişik duygulu cinsiyetçilik ölçeği: Geçerlik ve güvenirlik çalışması. (Ambivalent sexism scale: A study of validity and reliability). Türk Psikoloji Dergisi (The Journal of Turkish Psychology), 17(49), 47-58.

Sakall1-Uğurlu, N., \& Shaver, P. R. (2013). Religious orientation scale. Unpublished manuscript. Department of Psychology, Middle East Technical University, Ankara, Turkey.

Sakallı-Uğurlu, N., Yalçın, S. Z., \& Glick, P. (2007). Ambivalent sexism, belief in a just world, and empathy as predictors of Turkish students' attitudes toward rape victims. Sex Roles, 57(11/12), 889-895. 
Saroglou, V. (2002). Religion and the five factors of personality: A meta-analytic review. Personality and individual differences, 32, 15-25. http://dx.doi.org/10.1016/ S0191-8869(00)00233-6

Schwartz, S. H. (1994). Beyond individualism-collectivism: New cultural dimensions of values. In U. Kim, H. C. Triandis, C. Kagitcibasi, S-C, Choi and G. Yoon (Eds.). Individualism and collectivism: Theory, method and applications (p. 85-119). London: Sage.

Sibley, C. G., Overall, N. C., \& Duckitt, J. (2007). When women become more hostilely sexist toward their gender: The system-justifying effect of benevolent sexism. Sex Roles, 57, 743-754. http://dx.doi.org/10.1007/s11199-007-9306-1

Sunar, D. (1982). Female stereotypes in the U.S. and Turkey: An application of functional theory to perceptions in power relations. Journal of Cross Cultural Psychology, 13, 445-460.

Sünbüloğlu, N. Y. (2013). Erkek millet asker millet: Türkiye'de militarism, milliyetçilik, erkek(lik)ler. İstanbul: İletişimYayıncılık.

Taşdemir, N., \& Sakall1-Uğurlu, N. (2010). The relationships between ambivalent sexism and religiosity among Turkish university students. Sex Roles, 62, 420-426. http://dx.doi.org/10.1007/s11199-009-9693-6

Vaus, D., \& McAllister, I. (1987). Gender differences in religion: A test of the structural location theory. American Sociological Review, 52, 472-481.

Walby, S. (1990). Theorizing patriarchy. Oxford: Basic Blackwell.

World Economic Forum. (2014). The global gender gap report - 2014. Cologny, Geneva: World Economic Forum. Retrieved from http://www3.weforum.org/docs/GGGR14/GGGR_CompleteReport_2014.p df 